\title{
Fish Assemblage Changes in an Ozark River after Impoundment: A Long-Term Perspective
}

\author{
JEFFrey W. QUinN ${ }^{1}$ AND ThOMAS J. KWAK*2 \\ U.S. Geological Survey, \\ Arkansas Cooperative Fish and Wildlife Research Unit, ${ }^{3}$ \\ Department of Biological Sciences, University of Arkansas, \\ Fayetteville, Arkansas 72701, USA
}

\begin{abstract}
We conducted an intensive fish survey in the tailwater reach of a large Ozark river 30 years after its impoundment and compared the recent fish assemblage with those prior to impoundment and shortly (4 years) after impoundment. Our primary objective was to assess whether relatively short-term monitoring following dam construction can adequately quantify the long-term effects of impoundment on downstream riverine fishes. The preimpoundment survey (1962-1963) described a fish assemblage composed of warmwater fish species, predominantly Cyprinidae, Ictaluridae, Centrarchidae, and Percidae. Yoke darter Etheostoma juliae (34\%), central stoneroller Campostoma anomalum (24\%), and Ozark madtom Noturus albater (7\%) were the most abundant species. The postimpoundment surveys of 1965-1966 and 1968 documented immediate changes in the fish assemblage. No Ozark madtoms and only four yoke darters were collected shortly after impoundment. Central stonerollers accounted for $45-50 \%$ of the fish collected, and both short-term postimpoundment surveys collected five species of darters (Percidae) that accounted for $41-42 \%$ of the fish collected. Thirty years after impoundment, we found that the tailwater fish assemblage was composed almost entirely of coldwater species. Ozark sculpin Cottus hypselurus and four species of introduced trout (Salmonidae) accounted for $98 \%$ of the fish assemblage by number during the 1995-1997 surveys. The rank abundance of species was negatively correlated between our survey and the preimpoundment survey but not between our survey and the short-term postimpoundment surveys. Many species that we collected (54\%) are habitat generalists, and we did not collect $77 \%$ of the fluvial-specialist species that were present in historical collections. All postimpoundment surveys documented dramatically reduced species richness and diversity. We conclude that short-term monitoring following impoundment is inadequate to determine the impact of dams on lotic fish assemblages and suggest long-term postimpoundment monitoring to determine when a fish assemblage has stabilized.
\end{abstract}

Understanding how dramatic changes to the environment affect community structure is a major focus of aquatic ecology (Matthews 1998). The North American fish fauna has been subjected to a wide array of human-induced disturbances. Among the most widespread and drastic of disturbances has been the damming of rivers for hydroelectric power generation, flood control, recreational uses, and water storage (Brooker 1981; Benke 1990; Collier et al. 1996). Extensive liter-

\footnotetext{
* Corresponding author: tkwak@ncsu.edu

1 Present address: Arkansas Game and Fish Commission, 2 Natural Resources Drive, Little Rock, Arkansas 72205, USA.

2 Present address: U.S. Geological Survey, North Carolina Cooperative Fish and Wildlife Research Unit, Box 7617, North Carolina State University, Raleigh, North Carolina 27695, USA.

3 The Unit is jointly supported by the Arkansas Game and Fish Commission, University of Arkansas, U.S. Geological Survey, and Wildlife Management Institute.
}

Received November 19, 2001; accepted July 12, 2002 ature reviews have been compiled on the effects of river impoundment on downstream ecological communities (e.g., Brooker 1981; Walburg et al. 1981; Cushman 1985). However, the effects of river impoundment and regulation on downstream riverine fish assemblages have been poorly documented considering the extent to which North American rivers have been dammed (Benke 1990).

The White River of northern Arkansas and southern Missouri has been substantially modified by several large hydropower dams. The upper White River fish assemblage was sampled extensively by several early investigators (Jordan and Gilbert 1886; Black 1940; Knapp 1958; Keith 1964; B. Crawford and O. D. Brown, Arkansas Game and Fish Commission, unpublished report), and their collections now serve as a historical record of the fishes that occurred before Beaver Dam was constructed. Two short-term studies were completed after Beaver Dam became operational in 1965, and they were the first to document the fishes of Beaver Dam tailwater (sampling during 1965-1966, Brown et al. 1968; sampling during 
1968, Bacon et al. 1969). Thirty years later, we thoroughly sampled the fish assemblage of Beaver Dam tailwater from 1995 to 1997 in conjunction with an evaluation of instream and riparian habitat rehabilitation (Quinn 1998; Quinn and Kwak 2000). During our survey, we noticed that the fish assemblage had changed considerably since river impoundment and the earlier short-term studies. Therefore, we present a long-term perspective of the fish assemblage changes that occurred in the tailwater after construction of Beaver Dam, and we assess the importance of long-term monitoring to quantify the effects of impoundment on downstream riverine fishes.

\section{Study Area}

Located in Carroll County, Arkansas, Beaver Dam and its downstream, tailwater reach lie within the Ozark Mountains. Construction of Beaver Dam began in October 1959, Beaver Lake began filling in December 1963, and hydroelectric power generation was initiated during May 1965 (U.S. Army Corps of Engineers 1993). The dam is $70 \mathrm{~m}$ high and has two power generation turbines that release water from the reservoir's hypolimnion. Water temperature in the tailwater averages $10.0^{\circ} \mathrm{C}(\mathrm{SD}$ $=3.8^{\circ} \mathrm{C}$, range $=3.5-27.0^{\circ} \mathrm{C}$; U.S. Geological Survey, unpublished data). The drainage basin of Beaver Lake is $3,072 \mathrm{~km}^{2}$, and at power pool elevation the reservoir area is 11,420 ha. Beaver Dam tailwater drains into Table Rock Lake after flowing approximately $13 \mathrm{~km}$. Discharge ranged from $1 \mathrm{~m}^{3} / \mathrm{s}$ with no generators operating to 258 $\mathrm{m}^{3} / \mathrm{s}$ with both generators operating (Quinn 1998). Beaver Dam tailwater has been intensively managed by the Arkansas Game and Fish Commission as a coldwater, riverine trout (Salmonidae) fishery, and they stock rainbow trout Oncorhynchus mykiss, cutthroat trout $O$. clarki, brook trout Salvelinus fontinalis, and brown trout Salmo trutta $(175,000-$ 230,000 total trout/year) to supplement minimal natural trout reproduction (Pender and Kwak 2002).

\section{Methods}

Survey sampling techniques and regimes.-Keith (1964) studied the distribution and abundance of fishes in the upper White River before construction of Beaver Dam by collecting large numbers of fish from a broad geographic area during 1962-1963. We consider Keith's collections from a subset of 10 sites (section 4) to be the best representation of the fishes present before impoundment because most species had continuous distributions up- stream (Jordan and Gilbert 1886; Knapp 1958) and downstream (Keith 1964) of the present Beaver Dam tailwater. The electric seining technique that Keith (1964) used to collect fish differed from more recent designs (e.g., Bayley et al. 1989; Angermeier et al. 1991); it consisted of a $115-\mathrm{V}$, $1,000-\mathrm{W}$, AC generator, a variable-voltage pulsator, and two electrodes made of copper tubing and wire mesh mounted on bamboo poles. Riffles were sampled by blocking the downstream end with a seine (3.2- or 6.4-mm-mesh net) and electrofishing in a downstream direction. Deep pools were sampled with the same gear from a boat.

Brown et al. (1968) and Bacon et al. (1969) documented the fishes of Beaver Dam tailwater shortly after Beaver Dam was constructed and operating. Brown et al. (1968) collected fish from October 1965 to December 1966 at sites located $0.4,3.1$, and $5.6 \mathrm{~km}$ downstream of Beaver Dam. Brown et al. (1968) seined pools (3.2-mm mesh) and employed an electric seine in riffles. The electric seine was powered by a $115-\mathrm{V}, 1,000-\mathrm{W}$, AC generator and consisted of two electrodes that were used in combination with a 3.2-mm-mesh seine. In the summer of 1968, Bacon et al. (1969) resampled the collection sites of Brown et al. (1968). Bacon et al. (1969) collected fish in pools and riffles by electric seining and backpack electrofishing. Their modified electric seining technique employed a 3.2-mm-mesh seine, an unspecified electrode configuration, and a $115-\mathrm{V}, 3,000-\mathrm{W}$ generator.

We collected fish in two reaches of Beaver Dam tailwater (700-800 m long) using two methods in each reach. Nonbenthic species (primarily trout) were sampled at low flow (during the night in all habitats) with a boom-type, boat-mounted electrofisher. A 3,500-W generator supplied 220-V AC power to a Smith-Root Type VI-A variable-voltage pulsator to convert AC power to pulsed DC. Sampling dates for nonbenthic fishes were September and November 1995, April and October 1996, and June and October 1997. Benthic fishes (primarily sculpins Cottus spp.) were collected during the day in riffles and shallow pools by DC wade electrofishing with a Smith-Root Type VII backpack electrofisher, a Coffelt Mark 10 backpack electrofisher, or a bank electrofisher. The bank electrofisher consisted of a 1,500-W generator, a Smith-Root variable-voltage pulsator (Model 1.5 KVA), and two handheld anodes. Benthic fishes were sampled during January and March 1996 and January and March-April 1997. 
Fish assemblage structure and comparison.-We compiled all fish survey results according to species and family with catch expressed by number, and we calculated several assemblage-level indices based on those data. Assemblage indices included the number of species and families, species diversity (Shannon's $H^{\prime}$; Shannon and Weaver 1949), relative abundance, and the number of individuals and species for each of three macrohabitat-use guilds (fluvial specialist, fluvial restricted, and habitat generalist). Sample sizes of fish collected varied among surveys; therefore, we used a rarefaction method to estimate species richness independently of the number of individuals sampled in order to compare richness among samples (Hurlbert 1971). We also estimated total species richness for each sample using a nonparametric procedure described by Chao (1984). Macrohabitat-use categorizations by Bain (1992), Kinsolving and Bain (1993), and Travnichek et al. (1995) and habitat use and distribution information from Robison and Buchanan (1984) and Pflieger (1975) were followed to assign each species to a guild.

We used Spearman rank correlation to determine whether the rank abundance of species was correlated among assemblages (Zar 1996) using the 10 most abundant species from each assemblage in the analysis. Comparing assemblages similar in species composition yields a positive and significant correlation. If assemblages are significantly but negatively correlated, then species with high abundance in one assemblage have low abundance in the other. When the correlation is near zero, the two assemblages are considered independent.

We examined the effect of Beaver Dam on fish macrohabitat-use guilds. We expected that species that require riverine environments (i.e., fluvial specialists) would be extirpated from Beaver Dam tailwater, and we also expected that species that were habitat generalists would persist. Fluvialrestricted species require riverine environments only for spawning, and we predicted that they would be collected at least seasonally in Beaver Dam tailwater. Because fluvial-restricted species accounted for a small proportion of fish, we combined those species into the habitat generalist guild for analysis. The number of species in each macrohabitat guild was scored for each survey. Species frequencies of macrohabitat guilds were compared among surveys from 1962-1963 (Keith 1964), 1965-1966 (Brown et al. 1968), 1968 (Bacon et al. 1969), and 1995-1997 (Quinn 1998; present study) with a $G$-test for independence $(2 \times 4$ table; Zar 1996). It was determined a priori that if the test were significant pairwise $G$-tests for independence would be used to determine differences among surveys.

\section{Results}

Keith (1964) collected a total of 23,535 individual fish representing 62 species and 13 families in the upper White River before Beaver Dam was completed (Tables 1, 2, 3). He collected 19 species of Cyprinidae and 12 species of Percidae, and those families accounted for $75.1 \%$ of fish collected. The most abundant species found in the upper White River at that time included the yoke darter (34\%), central stoneroller (24\%), and Ozark madtom $(7 \%)$. Banded sculpins were not uncommon (382 collected), but Ozark sculpins were only collected near coolwater tributaries (2 individuals). Trout had not yet been introduced to the upper White River.

Brown et al. (1968) collected 1,193 fish that represent 18 species and 8 families during 19651966, and Bacon et al. (1969) collected 527 fish from 21 species and 7 families during 1968 (Tables $1,2,3)$. Central stonerollers accounted for $45-50 \%$ of fish collected in those two surveys shortly after dam construction, but few other cyprinid species were collected. Darters (Percidae) constituted 41$42 \%$ of fish collected by Brown et al. (1968) and Bacon et al. (1969), and both studies found 5 darter species. Ozark sculpins were not sampled in the two short-term surveys, and Brown et al. (1968) collected only 3 banded sculpins.

We collected 14,440 fish representing 28 species and 8 families during 1995-1997 (Tables 1, 2, 3). Ozark sculpins and trout comprised $98 \%$ of the fish that we captured. Using wade electrofishing, we collected 8 species from 3 families. The families Cyprinidae and Cottidae were represented by only 2 species. Percidae were represented by 4 species with low abundance. Ninety-eight percent of the 3,393 benthic fish collected were Ozark sculpins (3,330 individuals). We collected 20 species from 7 families by boat electrofishing. Similarly, $98 \%$ of the 11,047 nonbenthic fish collected by boat electrofishing were trout (four species; 10,860 individuals).

\section{Comparison among Fish Assemblages}

The families Cyprinidae, Ictaluridae, and Percidae appear to have been most affected by impoundment when data from all four surveys are compared (Tables 1 and 2). Keith (1964) collected 16 cyprinid species that we did not collect, and 
cyprinids made up only $0.1 \%$ of our fish collections (Tables 1 and 2). Keith (1964) collected 7 species of darters and 6 species of catfish that we did not. Percidae made up only $0.4 \%$ of our samples, and we collected no ictalurids. Our survey described a fish assemblage dramatically lower in richness and diversity than that of the preimpoundment survey but similar in those parameters to postimpoundment surveys performed immediately after dam construction (Table 3). Species richness estimates independent of sample size followed that same trend (Figure 1). The recent fish assemblage differs most dramatically from those sampled during the 1960s in that it is dominated by introduced trout species $(75 \%$ of the total) that are fluvial restricted in macrohabitat use, but it includes a substantial component of Ozark sculpins (23\%) that are spring-oriented fluvial specialists. We collected 11 species that were not captured during either short-term postimpoundment survey (Brown et al. 1968; Bacon et al. 1969), including 1 clupeid, 2 catostomids, 2 salmonids, 1 cottid, 1 percichthyid, and 4 centrarchids. We did not collect 12 species that were found by the short-term studies, including 4 cyprinids, 2 ictalurids, 2 cyprinodontids, 2 centrarchids, and 2 percids.

The rank abundance of species was not significantly correlated between the preimpoundment survey and short-term postimpoundment surveys from $1965-1966\left(r_{s}=0.28 ; P=0.144\right)$ or 1968 ( $\left.r_{s}=-0.04 ; P=0.834\right)$. The two short-term postimpoundment assemblages were significantly and positively correlated with each other $\left(r_{s}=0.54\right.$; $P=0.003)$. The rank abundance of species in our collections was significantly and negatively correlated with that of the preimpoundment survey $\left(r_{s}=-0.40 ; P=0.033\right)$, but our assemblage data were not significantly correlated with the two short-term postimpoundment surveys from 1965$1966\left(r_{s}=-0.25 ; P=0.200\right)$ or $1968\left(r_{s}=0.49\right.$; $P=0.483)$.

Significantly fewer fish species were fluvial specialists in our collections than in those of the preimpoundment survey ( $P<0.05$; Table 3$)$. We did not collect $77 \%$ of the fluvial-specialist species (27 of 35) occurring in the preimpoundment survey, and we collected only $52 \%$ of the habitat generalists that occurred in the preimpoundment survey. The frequency of macrohabitat-use guilds was independent among the four surveys $(G=8.25$; df $=3 ; P=0.041)$. Pairwise comparisons indicated that the macrohabitat guild distributions of the two short-term postimpoundment surveys were not independent of each other $(G=2.07$; df $=1$;
$P=0.150)$, and neither the 1965-1966 ( $G=0.13$; $\mathrm{df}=1 ; P=0.724)$ nor the 1968 survey $(G=2.12$; df $=1 ; P=0.145)$ was independent of the preimpoundment survey. We collected relatively fewer fluvial specialists than in the preimpoundment survey $(G=6.17$; df $=1 ; P=0.013)$ and the 1965 $1966(G=4.81$; df $=1 ; P=0.028)$ but not the 1968 survey $(G=0.49$; df $=1 ; P=0.483)$.

\section{Discussion}

Our temporal comparisons clearly demonstrate that short-term monitoring ( $<4$ years) was not adequate to document the changes that would ultimately occur in the upper White River fish assemblage after river impoundment. We documented substantial changes in the fish assemblage that occurred since short-term postimpoundment surveys were completed. We found that introduced trout and Ozark sculpins dominated the recent fish assemblage, but Ozark sculpins were absent from the short-term surveys. The short-term studies indicated that central stonerollers and darters remained abundant, but we found those taxa uncommon in the current fish assemblage. Thus, we conclude that short-term monitoring following impoundment is inadequate to determine the impact of dams on lotic ecosystems and recommend longterm monitoring to document the full extent of fish assemblage changes.

Although none of the postimpoundment surveys (including ours) collected fish in a standardized manner with constant effort, it is clear that our conclusions and recommendations are valid because of the dramatic long-term changes in the fish assemblage. We assumed that the early surveys of the upper White River (Keith 1964; Brown et al. 1968; Bacon et al. 1969) were representative of the fishes that occurred in Beaver Dam tailwater before impoundment and during the short-term postimpoundment period. We believe that this assumption was reasonable for species presence/absence and the rankings of species relative abundance. However, rotenone data (Crawford and Brown, unpublished report) indicated that large fishes occupying pool habitats, especially large catfishes, were not efficiently captured by the electric seining technique employed in early pre- and postimpoundment surveys.

Several species that we collected and that were not found by the previous postimpoundment studies were habitat generalists that appear to have migrated upstream from Table Rock Lake, the next reservoir downstream on the White River. Our seasonal sampling suggests that threadfin shad, white 
TABLE 1.-Fish collected from the Beaver Dam tailwater by species and macrohabitat guild in (1) a preimpoundment survey during 1962-1963 (Keith 1964), (2) two short-term postimpoundment surveys during 1965-1968 (Brown et al. 1968; Bacon et al. 1969), and (3) our recent survey (1995-1997). Macrohabitat guild classification includes fluvial specialist $(F)$, fluvial restricted $(R)$, and generalist $(G)$.

\begin{tabular}{|c|c|c|c|c|c|}
\hline \multirow[b]{2}{*}{ Species } & \multirow{2}{*}{$\begin{array}{c}\text { Macro- } \\
\text { habitat } \\
\text { guild }\end{array}$} & \multicolumn{4}{|c|}{ Number collected } \\
\hline & & $1962-1963$ & $1965-1966$ & 1968 & 1995-1997 \\
\hline Southern brook lamprey Ichthyomyzon gagei & $\mathrm{R}$ & 1 & & & \\
\hline Longnose gar Lepisosteus osseus & G & 8 & & & \\
\hline Gizzard shad Dorosoma cepedianum & G & 803 & 9 & 1 & 9 \\
\hline Threadfin shad D. petenense & G & & & & 1 \\
\hline Mooneye Hiodon tergisus & $\mathrm{R}$ & 2 & & & \\
\hline Cutthroat trout Oncorhynchus clarki & $\mathrm{R}$ & & & & 542 \\
\hline Rainbow trout $O$. mykiss & $\mathrm{R}$ & & & 2 & 4,945 \\
\hline Brown trout Salmo trutta & $\mathrm{R}$ & & & 1 & 3,901 \\
\hline Brook trout Salvelinus fontinalis & $\mathrm{R}$ & & & & 1,472 \\
\hline Central stoneroller Campostoma anomalum & $\mathrm{F}$ & 5,565 & 599 & 236 & 3 \\
\hline Goldfish Carassius auratus & G & 1 & & & \\
\hline Whitetail shiner Cyprinella galactura & $\mathrm{F}$ & 21 & 1 & & \\
\hline Steelcolor shiner $C$. whipplei & $\mathrm{F}$ & 285 & 1 & & \\
\hline Common carp Cyprinus carpio & G & 158 & & 2 & 6 \\
\hline Streamline chub Erimystax dissimilis & $\mathrm{F}$ & 215 & & & \\
\hline Striped shiner Luxilus chrysocephalus & $\mathrm{F}$ & 21 & & 1 & \\
\hline Duskystripe shiner L. pilsbryi & $\mathrm{F}$ & 321 & 3 & 2 & \\
\hline Hornyhead chub Nocomis biguttatus & $\mathrm{F}$ & 4 & & & \\
\hline Golden shiner Notemigonus crysoleucas & G & 9 & & & \\
\hline Bigeye chub Notropis amblops & $\mathrm{F}$ & 10 & & & \\
\hline Bigeye shiner $N$. boops & $\mathrm{F}$ & 116 & & & \\
\hline Wedgespot shiner $N$. greenei & $\mathrm{F}$ & 1 & & & \\
\hline Ozark minnow $N$. nubilus & $\mathrm{F}$ & 3 & & & \\
\hline Ozark shiner $N$. ozarcanus & $\mathrm{F}$ & 11 & & & \\
\hline Roseyface shiner $N$. rubellus & $\mathrm{F}$ & 376 & & & \\
\hline Southern redbelly dace Phoxinus erythrogaster & $\mathrm{F}$ & 1 & & & \\
\hline Bluntnose minnow Pimephales notatus & G & 306 & & 1 & 1 \\
\hline Slim minnow $P$. tenellus & $\mathrm{F}$ & 7 & & & \\
\hline Quillback Carpiodes cyprinus & G & 3 & & & \\
\hline Highfin carpsucker $C$. velifer & $\mathrm{F}$ & 15 & & & \\
\hline Northern hog sucker Hypentelium nigricans & $\mathrm{F}$ & 298 & 4 & 1 & 1 \\
\hline River redhorse Moxostoma carinatum & $\mathrm{F}$ & 54 & & & \\
\hline Black redhorse $M$. duquesnei & $\mathrm{F}$ & 221 & & & 15 \\
\hline Golden redhorse $M$. erythrurum & $\mathrm{R}$ & 167 & & & 69 \\
\hline Black bullhead Ameiurus melas & G & & & 3 & \\
\hline Yellow bullhead $A$. natalis & G & 3 & & & \\
\hline Channel catfish Ictalurus punctatus & $\mathrm{G}$ & 147 & 1 & & \\
\hline Ozark madtom Noturus albater & $\mathrm{F}$ & 1,702 & & & \\
\hline Slender madtom $N$. exilis & $\mathrm{F}$ & 63 & & & \\
\hline Checkered madtom $N$. flavater & $\mathrm{F}$ & 2 & & & \\
\hline Flathead catfish Pylodictis olivaris & $\mathrm{R}$ & 83 & & & \\
\hline Northern studfish Fundulus catenatus & $\mathrm{F}$ & 25 & 2 & & \\
\hline Blackspotted topminnow $F$. olivaceus & $\mathrm{G}$ & 60 & 7 & & \\
\hline Brook silverside Labidesthes sicculus & G & 60 & & & \\
\hline White bass Morone chrysops & G & & & & 6 \\
\hline Ozark bass Ambloplites constellatus & $\mathrm{G}$ & 1 & & & \\
\hline Green sunfish Lepomis cyanellus & G & 69 & 1 & 39 & 49 \\
\hline Warmouth L. gulosus & G & & & & 1 \\
\hline Bluegill L. macrochirus & G & 164 & 3 & 3 & 14 \\
\hline Longear sunfish L. megalotis & G & 727 & & 5 & 2 \\
\hline Redear sunfish L. microlophus & G & & & 1 & \\
\hline Smallmouth bass Micropterus dolomieu & G & 24 & & & 2 \\
\hline Spotted bass $M$. punctulatus & $\mathrm{G}$ & 674 & & 1 & 4 \\
\hline Largemouth bass $M$. salmoides & G & 83 & 23 & 6 & \\
\hline White crappie Pomoxis annularis & G & 3 & & & 5 \\
\hline Black crappie $P$. nigromaculatus & G & 17 & & & 1 \\
\hline Greenside darter Etheostoma blennioides & $\mathrm{F}$ & 170 & & 3 & 1 \\
\hline Rainbow darter E. caeruleum & $\mathrm{F}$ & 370 & 391 & 35 & 45 \\
\hline Arkansas saddled darter E. euzonum & $\mathrm{F}$ & 82 & & & \\
\hline Yoke darter $E$. juliae & $\mathrm{F}$ & 8,104 & 4 & & \\
\hline
\end{tabular}


TABLE 1.-Continued.

\begin{tabular}{|c|c|c|c|c|c|}
\hline \multirow[b]{2}{*}{ Species } & \multirow{2}{*}{$\begin{array}{l}\text { Macro- } \\
\text { habitat } \\
\text { guild }\end{array}$} & \multicolumn{4}{|c|}{ Number collected } \\
\hline & & $1962-1963$ & 1965-1966 & 1968 & 1995-1997 \\
\hline Stippled darter E. punctulatum & $\mathrm{F}$ & 1 & 1 & 28 & 3 \\
\hline Orangethroat darter $E$. spectabile & $\mathrm{F}$ & 1 & 48 & 110 & \\
\hline Speckled darter E. stigmaeum & $\mathrm{F}$ & 8 & & & \\
\hline Banded darter $E$. zonale & $\mathrm{F}$ & 743 & & & \\
\hline Logperch Percina caprodes & G & 470 & 92 & 46 & 6 \\
\hline Gilt darter $P$. evides & $\mathrm{F}$ & 278 & & & \\
\hline Longnose darter $P$. nasuta & $\mathrm{F}$ & 5 & & & \\
\hline Walleye Stizostedion vitreum & G & 4 & & & 2 \\
\hline Freshwater drum Aplodinotus grunniens & G & 5 & & & \\
\hline Ozark sculpin Cottus hypselurus & $\mathrm{F}$ & $2^{\mathrm{a}}$ & & & 3,330 \\
\hline Banded sculpin $C$. carolinae & $\mathrm{F}$ & 382 & 3 & & 4 \\
\hline Total & & 23,535 & 1,193 & 527 & 14,440 \\
\hline
\end{tabular}

a Originally reported as mottled sculpin Cottus bairdi; described later as Ozark sculpin (Robins and Robison 1985).

bass, warmouth, smallmouth bass, white crappie, and black crappie were probably short-term residents of Beaver Dam tailwater that migrated upstream from Table Rock Lake. We observed paddlefish Polyodon spathula and striped bass Morone saxatilis seasonally in Beaver Dam tailwater, but we were unable to collect those species.

\section{Ecological and Management Implications}

Macrohabitat-use guild information appears to be useful for predicting the identity of species likely to be extirpated after dam construction, as we did not collect $77 \%$ of the fluvial-specialist species found in preimpoundment collections. We are unaware of other ecological models that could be used to predict species presence/absence after river regulation. However, using macrohabitat guilds as a predictive model has shortcomings that may limit its application in other situations. The ichthyolo- gists who compiled and developed the information used to assign the majority of species to a macrohabitat guild (Robison and Buchanan 1984) probably had considerable knowledge of which species were influenced by dams. Additionally, regulated rivers often have substantial longitudinal recovery gradients (e.g., Kinsolving and Bain 1993), so that other applications may need to adjust the predictions from the macrohabitat model according to distance downstream from the dam. Despite the macrohabitat model's limitations, we maintain that a macrohabitat-use guild framework is a useful tool for predicting the effects of impoundment on riverine fishes. Empirical studies that classify species into habitat guilds, such as the shallow, slowwater guild of Bain et al. (1988), could be useful a priori for predicting species persistence or extirpation after impoundment. Incorporating other environmental and physiological influences on a

TABLE 2.- Relative abundance (number of species in parentheses) by family of fish collected from the Beaver Dam tailwater in the three surveys noted in Table 1.

\begin{tabular}{|c|c|c|c|c|}
\hline \multirow[b]{2}{*}{ Family } & \multicolumn{4}{|c|}{ Percent collected } \\
\hline & $1962-1963$ & 1965-1966 & 1968 & 1995-1997 \\
\hline Petromyzontidae & $<0.1$ (1) & & & \\
\hline Lepisosteidae & $<0.1$ (1) & & & \\
\hline Clupeidae & $3.4(1)$ & $0.7(1)$ & $0.2(1)$ & $0.1(2)$ \\
\hline Hiodontidae & $<0.1$ (1) & & & \\
\hline Salmonidae & & & $0.6(2)$ & $75.2(4)$ \\
\hline Cyprinidae & $31.6(19)$ & $50.7(4)$ & $45.9(5)$ & $0.1(3)$ \\
\hline Catostomidae & $3.2(6)$ & $0.3(1)$ & $0.2(1)$ & $0.6(3)$ \\
\hline Ictaluridae & $8.5(6)$ & $0.1(1)$ & $0.6(1)$ & \\
\hline Cyprinodontidae & $0.4(2)$ & $0.7(2)$ & & \\
\hline Atherinidae & $0.3(1)$ & & & \\
\hline Percichthyidae & & & & $<0.1$ (1) \\
\hline Centrarchidae & $7.5(9)$ & $2.3(3)$ & $10.4(6)$ & $0.5(8)$ \\
\hline Percidae & $43.5(12)$ & $44.9(5)$ & $42.1(5)$ & $0.4(5)$ \\
\hline Sciaenidae & $<0.1$ (1) & & & \\
\hline Cottidae & $1.6(2)$ & $0.3(1)$ & & $23.1(2)$ \\
\hline
\end{tabular}


TABLE 3.-Indices of the assemblage structure of fish collected from the Beaver Dam tailwater in the three surveys noted in Table 1.

\begin{tabular}{|c|c|c|c|c|}
\hline Index & $1962-1963$ & 1965-1966 & 1968 & 1995-1997 \\
\hline Number of species & 62 & 18 & 21 & 28 \\
\hline \multicolumn{5}{|l|}{ Expected number of species } \\
\hline (standardized to $N=500$ individuals) $^{\mathrm{a}}$ & 33.9 & 13.9 & 20.6 & 10.2 \\
\hline Estimated total number of species ${ }^{b}$ & 70.2 & 30.5 & 29.2 & 34.0 \\
\hline Number of families & 13 & 8 & 7 & 8 \\
\hline Species diversity & 2.38 & 1.31 & 1.76 & 1.52 \\
\hline \multicolumn{5}{|l|}{ Fluvial specialist } \\
\hline Percent by number & 82.8 & 88.6 & 78.9 & 23.6 \\
\hline Percent of species & 56.4 & 61.1 & 38.1 & 28.5 \\
\hline \multicolumn{5}{|l|}{ Fluvial restricted } \\
\hline Percent by number & 1.1 & 0 & 0.6 & 75.7 \\
\hline Percent of species & 6.5 & 0 & 9.5 & 17.9 \\
\hline \multicolumn{5}{|l|}{ Generalist } \\
\hline Percent by number & 16.1 & 11.4 & 20.5 & 0.7 \\
\hline Percent of species & 37.1 & 38.9 & 52.4 & 53.6 \\
\hline
\end{tabular}

species, such as temperature preferences (stenothermal versus eurythermal) or body morphology (e.g., Wood and Bain 1995), could improve the predictive power of future models. Similarly, such guild and species models could be used to predict the changes in fish assemblage in rivers that are candidates for restoration via dam removal.

The rarefaction and extrapolation procedures that we used to estimate species richness were particularly appropriate for fish assemblage samples from surveys varying in effort and catch. Rarefaction was originally developed by Sanders (1968) to compare marine benthic invertebrate as- semblages, and it was later corrected for bias by Hurlbert (1971). This procedure rarifies a large sample to estimate species richness for subsamples of fewer individuals, thereby allowing comparison of expected species richness for common sizes among samples (Figure 1). Several assumptions associated with rarefaction limit its application and affect the interpretation of results. These include similarity in sampling techniques, habitats, surface area, and organisms among samples and that individuals are randomly distributed spatially and sampled independently of one another (Sanders 1968; Hurlbert 1971; Gotelli and Graves 1996).

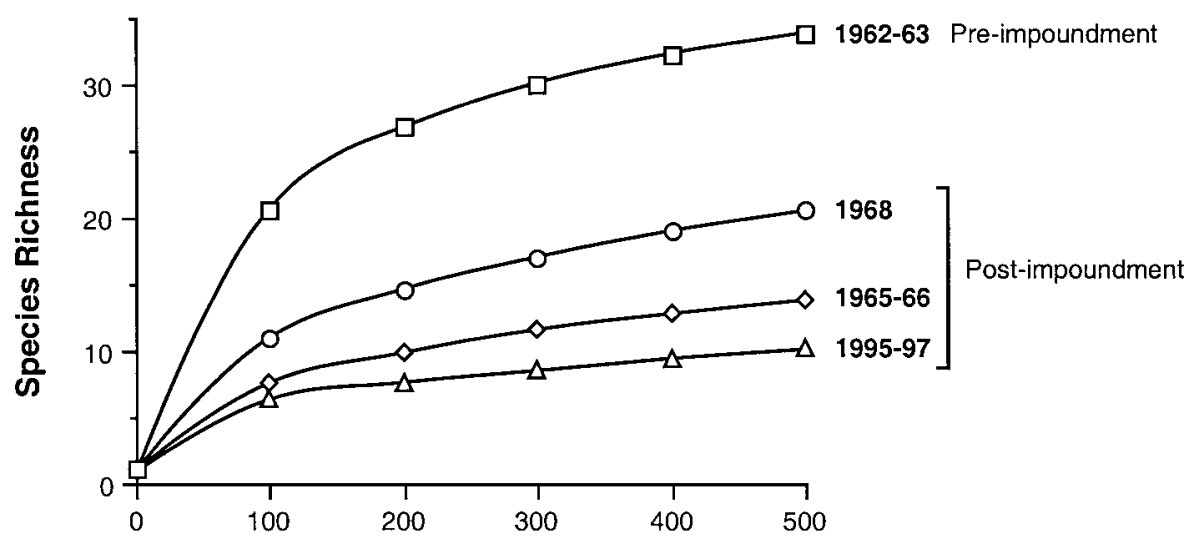

Sample Size (Number of Individuals)

FIGURE 1.-Rarefaction curves estimating species richness (number of species) according to survey sample size (number of individuals) to facilitate comparisons among surveys independent of sample size. Data include fish collected from the Beaver Dam tailwater in a preimpoundment survey during 1962-1963 (Keith 1964), two shortterm postimpoundment surveys during 1965-1968 (Brown et al. 1968; Bacon et al. 1969), and our recent survey (1995-1997). 
These assumptions were violated to varying degrees of acceptability in our analysis, as fish assemblages are rarely randomly distributed or sampled independently in a field setting. However, any sampling bias was likely consistent among surveys. Further, the nonparametric procedure that we used to estimate total species richness required extrapolation outside the bounds of our data, and we interpret these results with caution, emphasizing trends rather than exact estimates.

Our research documents a dramatic, long-term change in the riverine fish assemblage following dam construction and impoundment, but among the numerous proximate effects of dams on rivers (NRC 1992; Collier et al. 1996) we were unable to elucidate the ones that brought these changes about (e.g., Freeman et al. 2001; Marchetti and Moyle 2001). The fish assemblage of Beaver Dam tailwater was transformed from one composed of warmwater fish species, predominantly Cyprinidae, Ictaluridae, Centrarchidae, and Percidae, to the present one dominated by coldwater fishes, namely, Ozark sculpins and introduced trout. This observation suggests that changes in the thermal environment caused by hypolimnetic water releases downstream of the dam are likely a controlling factor, but other physical alterations, such as those related to the variation in flow associated with peaking hydropower generation, water chemistry (especially dissolved oxygen), the disruption of fish migration, and sediment and organic matter flow, may also be important. Furthermore, changes in the biotic environment following impoundment may have facilitated the shift in the fish assemblage; these include the introduction and stocking of trout for the sport fishery and an influx of lentic piscivores from the next downstream reservoir.

While we have documented changes in the fish assemblage of this Ozark river, we cannot speculate more precisely on the timing of the observed changes. Glowacki and Penczak (2000) found that fish species richness declined continually over an 11-year period after construction of a dam on the Warta River, Poland. One group of investigators that surveyed Beaver Dam tailwater 3 years after impoundment correctly warned that "the ichthyofauna in the Beaver Reservoir tailwaters have not reached a stable condition" (Bacon et al. 1969). Thus, the question remains as to the duration of monitoring that is sufficient to detect the effects of impoundment on the fish assemblage. The answer to this question certainly varies among ecosystems and should be addressed empirically with a monitoring program. Long-term monitoring pro- grams using standardized fish sampling techniques should be planned at the earliest stages of major water development projects. Methods to detect trends over time, including the techniques that we employed and those reviewed and proposed by Thompson et al. (1998), which are applicable to more complete data sets, could be used to determine when a fish assemblage has stabilized and monitoring may be reduced or curtailed.

Our research highlights the importance of the temporal scale in monitoring fish assemblages. Surveys conducted before and shortly after impoundment or other substantial disturbance are unlikely to detect the full magnitude of effects. Regulatory agencies and river managers may have concluded that Beaver Dam did not cause a serious decline in the abundance of central stonerollers and darters if they based their decisions only on short-term postimpoundment monitoring (e.g., Brown et al. 1968). This inaccurate conclusion would have stemmed from limited data. While regulatory and management agencies strive for efficiency in developing monitoring programs, limiting the resources and requirements for monitoring may result in inappropriate management actions and inadequate mitigation for environmental losses.

Virtually every river in the 48 conterminous United States is now regulated in some way (Collier et al. 1996). Over 75,000 dams impound rivers in the United States; more are planned for the future, and many from the past are undergoing relicensing and review (NRC 1992; Collier et al. 1996). The findings of our temporal comparison compel careful planning and deliberation in the development of the monitoring programs and ecological assessments associated with these projects.

\section{Acknowledgments}

We are grateful to J. H. Herner-Thogmartin, D. A. Lichtenberg, D. R. Pender, C. M. Pevey, R. D. Rambo, and numerous volunteers for assistance collecting field data. We thank L. L. Rider and S. P. Filipek of the Arkansas Game and Fish Commission and S. Eager of the Arkansas Chapter of Trout Unlimited for their support of this research. S. Bays and J. Kielczeweski of the U.S. Army Corps of Engineers and D. Kennedy and L. Wells of the Southwestern Power Administration facilitated planning for river access. M. B. Bain, F. C. Fiss, W. E. Keith, and V. H. Travnichek provided constructive manuscript reviews. Financial support for this research was provided by the Arkansas Chapter of Trout Unlimited and the Arkansas 
Game and Fish Commission through Federal Aid in Sport Fish Restoration funds (F-63, Project H, Study VI).

\section{References}

Angermeier, P. L., R. A. Smoger, and S. D. Steele. 1991. An electric seine for collecting fish in streams. North American Journal of Fisheries Management 11:352-357.

Bacon, E. J., Jr., S. H. Newton, R. V. Kilambi, and C. E. Hoffman. 1969. Changes in the ichthyofauna in the Beaver Reservoir tailwaters. Proceedings of the Annual Conference Southeastern Association of Game and Fish Commissioners 22(1968):245-248.

Bain, M. B. 1992. Study designs and sampling techniques for community-level assessment of large rivers. Biological assessments in large rivers. North American Benthological Society 5th Annual Technical Information Workshop, Louisville, Kentucky.

Bain, M. B., J. T. Finn, and H. E. Booke. 1988. Streamflow regulation and fish community structure. Ecology 69:382-392.

Bayley, P. B., R. W. Larimore, and D. C. Dowling. 1989. Electric seine as a fish-sampling gear in streams. Transactions of the American Fisheries Society 118: 447-453.

Benke, A. C. 1990. A perspective on America's vanishing streams. Journal of the North American Benthological Society 9:77-88.

Black, J. D. 1940. The distribution of the fishes of Arkansas. Doctoral dissertation. University of Michigan, Ann Arbor.

Brooker, M. P. 1981. The impact of impoundments on the downstream fisheries and general ecology of rivers. Advances in Applied Biology 6:91-152.

Brown, J. D., C. R. Liston, and R. W. Dennie. 1968. Some physico-chemical and biological aspects of three cold tailwaters in northern Arkansas. Proceedings of the Annual Conference Southeastern Association of Game and Fish Commissioners 21(1967):369-381.

Chao, A. 1984. Non-parametric estimation of the number of classes in a population. Scandinavian Journal of Statistics 11:265-270.

Collier, M., R. H. Webb, and J. C. Schmidt. 1996. Dams and rivers: a primer on the downstream effects of dams. U.S. Geological Survey Circular 1126.

Cushman, R. M. 1985. Review of ecological effects of rapidly varying flows downstream from hydroelectric facilities. North American Journal of Fisheries Management 5:330-339.

Freeman, M. C., Z. H. Bowen, K. D. Bovee, and E. R. Irwin. 2001. Flow and habitat effects on juvenile fish abundance in natural and altered flow regimes. Ecological Applications 11:179-190.

Glowacki, L., and T. Penczak. 2000. Impoundment impact on fish in the Warta River: species richness and sample size in the rarefaction method. Journal of Fish Biology 57:99-108.

Gotelli, N. J., and G. R. Graves. 1996. Null models in ecology. Smithsonian Institution Press, Washington, D.C.

Hurlbert, S. H. 1971. The nonconcept of species diversity: a critique and alternative parameters. Ecology 52:577-586.

Jordan, D. S., and C. H. Gilbert. 1886. List of fishes collected in Arkansas, Indian Territory, and Texas, in September, 1884, with notes and descriptions. Proceedings of the United States National Museum 9:1-25.

Keith, W. E. 1964. A pre-impoundment study of the fishes, their distribution and abundance, in the Beaver Lake drainage of Arkansas. Master's thesis. University of Arkansas, Fayetteville.

Kinsolving, A. D., and M. B. Bain. 1993. Fish assemblage recovery along a riverine disturbance gradient. Ecological Applications 3:531-544.

Knapp, L. W. 1958. A distributional study of the fishes of the upper White River, Missouri. Master's thesis. University of Missouri, Columbia.

Marchetti, M. P., and P. B. Moyle. 2001. Effects of flow regime on fish assemblages in a regulated California stream. Ecological Applications 11:530-539.

Matthews, W. J. 1998. Patterns in freshwater fish ecology. Chapman and Hall, New York.

NRC (National Research Council). 1992. Restoration of aquatic ecosystems: science, technology, and public policy. National Academy Press, Washington, D.C.

Pender, D. R., and T. J. Kwak. 2002. Factors influencing brown trout reproductive success in Ozark tailwater rivers. Transactions of the American Fisheries Society 131:698-717.

Pflieger, W. C. 1975. Fishes of Missouri. Missouri Department of Conservation, Jefferson City.

Quinn, J. W. 1998. Fish populations and trout microhabitat use of rehabilitated habitat in an Ozark tailwater river. Master's thesis. University of Arkansas, Fayetteville.

Quinn, J. W., and T. J. Kwak. 2000. Use of rehabilitated habitat by brown trout and rainbow trout in an Ozark tailwater river. North American Journal of Fisheries Management 20:737-751.

Robins, C. R., and H. W. Robison. 1985. Cottus hypselurus, a new cottid fish from the Ozark Uplands, Arkansas and Missouri. American Midland Naturalist 114:360-373.

Robison, H. W., and T. M. Buchanan. 1984. Fishes of Arkansas. University of Arkansas Press, Fayetteville.

Sanders, H. L. 1968. Marine benthic diversity: a comparative study. American Naturalist 102:243-282.

Shannon, C. E., and W. Weaver. 1949. The mathematical theory of communication. University of Illinois Press, Urbana.

Thompson, W. L., G. C. White, and C. Gowan. 1998. Monitoring vertebrate populations. Academic Press, San Diego, California.

Travnichek, V. H., M. B. Bain, and M. J. Maceina. 1995. Recovery of a warmwater fish assemblage after the initiation of a minimum-flow release downstream from a hydroelectric dam. Transactions of the American Fisheries Society 124:836-844. 
U.S. Army Corps of Engineers. 1993. Water resources development in Arkansas. U.S. Army Engineer District, Little Rock, Arkansas.

Walburg, C. H., J. F. Novotny, K. E. Jacobs, W. D. Swink, T. M. Campbell, J. M. Nestler, and G. E. Saul. 1981. Effect of reservoir releases on tailwater ecology: a literature review. U.S. Army Engineer
Waterways Experiment Station, Technical Report E81-12, Vicksburg, Mississippi.

Wood, B. M., and M. B. Bain. 1995. Morphology and microhabitat use in stream fish. Canadian Journal of Fisheries and Aquatic Sciences 52:1487-1498.

Zar, J. H. 1996. Biostatistical analysis, 3rd edition. Prentice Hall, Upper Saddle River, New Jersey. 